\title{
Evaluation of the stability of thighs and drumsticks boneless chicken under different conditions of industrial storage
}

\author{
Juliana SAVIO ${ }^{1}$, Natalia PAROUL ${ }^{2}$, Geciane Toniazzo BACKES ${ }^{2}$, Eunice VALDUGA ${ }^{2}$, Débora de OLIVEIRA², \\ Juliana BARBOSA², Rogério Luis CANSIAN ${ }^{2 *}$
}

\begin{abstract}
The sensory, physical-chemical and microbiological characteristics of boneless chicken thighs and drumsticks stored at different temperatures were evaluated. Samples stored at -6 and $-12^{\circ} \mathrm{C}$, in natura and cooked, presented changes in sensory characteristics from the sixth and fifth month of storage, respectively. In natura samples kept at $-18^{\circ} \mathrm{C}$ presented sensory modification from the eighth month, and cooked samples did not show alterations during 12 months of storage. For lipid oxidation, differences were observed between -6 and $-12{ }^{\circ} \mathrm{C}$ by the third month and between -12 and $-18^{\circ} \mathrm{C}$ after 12 months of storage. Related to protein oxidation, samples stored at $-18^{\circ} \mathrm{C}$ did not differ from the standard ( 0 days), showing values of $6.03 \mathrm{nmol}$ carbonyl $/ \mathrm{mg}$ protein after 12 months of storage. Samples under freezing at $-6^{\circ} \mathrm{C}$ for 12 months presented an increase in psychrotrophic count. This behaviour was not observed in the samples stored at -12 and $-18^{\circ} \mathrm{C}$. Considering the different analyzes, the maximum storage period was 6 days at $4{ }^{\circ} \mathrm{C}, 8$ months at -6 and $-12{ }^{\circ} \mathrm{C}$ and at least 12 months storage at $-18{ }^{\circ} \mathrm{C}$.
\end{abstract}

Keywords: chicken; freezing; stability; storage.

Practical Application: The influence of temperature-time relationship are important for decision-making on storage of chicken products and meet the requirements of the international market for export.

\section{Introduction}

The consumption of frozen and chilled food has grown above average in recent years. Food security and control are, therefore, matters of great preoccupation for consumers. Consumer reliability on frozen and chilled food, especially related to aspects of the supply chain, is of high priority for all involved in the production, commercialization, logistics and distribution of foods (Galarz et al., 2010; Murray et al., 2017).

The industries have, however, some challenges, and it is necessary to determine the efficiency and competitiveness of the poultry industry compared to the industries of other meat sources and non-meat protein sources (Barbut, 2002). It is necessary to keep the stability of the quality characteristics of chicken during its production, distribution, storage and commercialization. In this sense, controls of hygiene and product temperature are, obviously, very important factors (Jayas \& Jeyamkondan, 2002; Elsedig et al., 2015).

Foods stored at improper temperatures can have their organoleptic and microbiological characteristics changed, affecting the health of consumers. The shelf life of the product can be reduced, leading to economic losses (Andrade et al., 2004; Mürmann et al., 2004; Conceição \& Gonçalves, 2009; Osimani et al., 2013; Morachis-Valdez et al., 2017).
The conservation of meats by freezing has great capacity for keeping the chemical, organoleptic and nutritive characteristics close to those of fresh foods, and also making difficult the undesirable action of microorganisms and enzymes (Southgate, 1992). Some changes can occur in chicken meat during storage under freezing such as softness, colour and development of strange tastes (Yoon, 2002). The literature points out that the sensory properties of chicken breast meat seem not to be significantly affected by storage under freezing (Lyon \& Lyon, 2002). However, as the temperature is reduced the chemical, physical and biochemical reactions that promote sensory alterations can occur at a low initial rate, but are not halted even when the food is stored at $-30{ }^{\circ} \mathrm{C}$ (Paine \& Paine, 1983).

Meat freezing is fast, and almost $75 \%$ of tissue fluid freezes at $-5^{\circ} \mathrm{C}$. The freezing rate is increased with decreases in temperature; almost $98 \%$ of water freezes at $-20^{\circ} \mathrm{C}$ and complete crystal formation occurs at $-65^{\circ} \mathrm{C}$ (Rosmini et al., 2004). However, more than $10 \%$ of muscle-bound water (chemically bound to specific sites such as carbonyl and amino groups of proteins and hydrogen bonding) will not freeze (Dave \& Ghaly, 2011).

Aiming at offering high-value products to the final consumer and considering the differentiated demands of Brazilian legislation, 
which states that products for the domestic market must have minimal temperatures of $-12{ }^{\circ} \mathrm{C}$ (Brasil, 1998) and those for exportation should reach -18 or $-20^{\circ} \mathrm{C}$, it is necessary to know the possible physical-chemical and microbiological alterations in these products. However, due to many variables such as the type and size of the cold chambers and the amount of raw material, changes observed in laboratory conditions may differ from those found in situ industrial conditions. Although there are studies evaluating meat product changes under freezing, there are few studies in industrial conditions, which justifies this work. Based on these aspects, the objective of this work is to evaluate the influence of different storage temperatures $\left(4,-6,-12\right.$ and $\left.-18^{\circ} \mathrm{C}\right)$ on the sensory, oxidative (protein and lipid) and microbiological stability of chicken boneless thighs and drumsticks.

\section{Materials and methods}

\subsection{Sample preparation}

Samples of boneless chicken thighs and drumsticks were taken directly from the production line ( 24 units of about $2 \mathrm{~kg}$ each) and packed in polyethylene bags $(24 \times 35 \mathrm{~cm}, 12 \mu \mathrm{m})$, submitted to a vacuum $(-750 \mathrm{mmHg})$, placed in cardboard boxes ( 6 packages/box) and stored in temperature-controlled chambers, following the same procedures adopted by the industry. Samples were separated into four different treatments: cooled at $4{ }^{\circ} \mathrm{C}$ for 8 days or frozen at $-6,-12$ and $-18^{\circ} \mathrm{C}$ for 12 months, in different cold rooms of a large slaughterhouse of South Region of Brazil.

At appropriate intervals of time, random samples were removed from the chambers, thawed in a refrigerator at $4{ }^{\circ} \mathrm{C}$ for 12 to $24 \mathrm{~h}$ and submitted to sensory, physical-chemical (total acidity, lipid oxidation, protein oxidation and $\mathrm{pH}$ ) and microbiological (psychrotrophic counting) analysis, following the methodologies described below.

\subsection{Physical-chemical analysis}

The $\mathrm{pH}$ and titratable acidity were measured using AOAC standards (Association of Official Analytical Chemists, 1990). Total acidity was determined following the methodology of Terra \& Brum (1998) and expressed as $\mathrm{g}$ of oleic acid per $100 \mathrm{~g}$ of sample. Water activity (aw) was determined by the standard procedure of the Aqualab CX-2 Water Activity System, performing calibration of the equipment using deionized water and a solution of $\mathrm{NaCl}$ with an aw value of 0.819 until stabilization, followed by reading of the aw/temperature $\left({ }^{\circ} \mathrm{C}\right)$ of the sample.

Lipid oxidation was measured by a spectrophotometer (Perkin Elmer model Lambda EZ150) at $531 \mathrm{~nm}$ using a standard curve with TEP $\left(10^{-8}\right.$ to $\left.10^{-7} \mathrm{~mol} / \mathrm{mL}\right)$ with thiobarbituric acid reactive substances (TBARS) following the methodology proposed by Raharjo et al. (1992) and modified. This analysis constitutes an estimation of lipid oxidation, since it determines substances reactive to thiobarbituric acid. Results were expressed in $\mathrm{mg}$ of malondialdehyde (MDA) per $\mathrm{kg}$ of product.

Protein oxidation was measured by assessment of carbonyl groups formed during the experiment using the methodology proposed by Levine et al. (1990) with slight modifications.
The concentration of protein was measured at $280 \mathrm{~nm}$ in the hydrochloric acid $(\mathrm{HCl})$ control using bovine serum albumin (BSA) in $6 \mathrm{M}$ guanidine as standard. The carbonyl concentration in the treated sample was measured with 2,4-dinitrophenylhydrazine (DNPH) incorporated on the basis of a molar absorption coefficient of $21.0 \mathrm{nM}^{-1} \cdot \mathrm{cm}^{-1}$ at $370 \mathrm{~nm}$ of protein hydrazones. Results were expressed as nmol of DNPH per mg of protein (De Paula et al., 2017).

\subsection{Microbiological analysis}

The total count of psychrotrophic microorganisms was carried out using the methodology of inoculation of $1 \mathrm{~mL}$ of each dilution by plating on a surface with counting agar (PCA), and incubation of dry, reversed plates at $7^{\circ} \mathrm{C}$ for 10 days (Altunatmaz et al., 2012; O’Connell et al., 2016).

\subsection{Sensory evaluation}

Sensory tests were carried out by 10 trained assessors of both sexes, 20 to 50 years old, all employees of Industry research \& development sector which follows specific labour legislation concerning this type of analysis. Samples of thighs and drumsticks were presented in two different sections: in natura, to evaluate appearance and flavour, and cooked, to evaluate taste and odour. Samples were sub-divided into pieces about $1.5 \times 1.5 \mathrm{~cm}$, and distributed in a balanced way in cups, coded with three random digits. Product acceptability was evaluated by the method of a hedonic scale of nine points, following the methodology described by Faria \& Yotsuyanagi (2002), based on a standard sample (0 days).

\subsection{Statistical analysis}

Results were statistically evaluated by analysis of variance, followed by Tukey's and Dunnett's tests at a significance level of $5 \%(\mathrm{p}<0.05)$ to compare the means of physical-chemical and sensory analysis, respectively.

\section{Results and discussion}

\subsection{Physical-chemical analysis}

The total acidity of chicken boneless thighs and drumsticks did not present a significant difference $(\mathrm{p}<0.05)$ during 8 days of storage at $4{ }^{\circ} \mathrm{C}$. The values were around $0.29 \pm 0.05 \mathrm{~g}$ oleic $\mathrm{acid} / 100 \mathrm{~g}$ product. Table 1 presents the results of total acidity of the samples stored at $-6,-12$ and $-18{ }^{\circ} \mathrm{C}$.

Samples stored at these temperatures presented a similar behaviour during storage, showing a significant increase $(\mathrm{p}<0.05)$ in oleic acid content (wt\%) from the eighth month of storage. Samples stored at $-12{ }^{\circ} \mathrm{C}$ kept a lower acidity index until the fourth month and those at $-18{ }^{\circ} \mathrm{C}$ until the eighth month, compared to the samples stored at $-6^{\circ} \mathrm{C}$.

The $\mathrm{pH}$ values of chicken boneless thighs and drumsticks did not present a significant difference $(\mathrm{p}<0.05)$ between the treatments submitted to refrigeration $\left(4^{\circ} \mathrm{C} / 8\right.$ days $)$ and freezing $\left(-6,-12\right.$ and $-18{ }^{\circ} \mathrm{C} / 12$ months), with mean values from 6.38 to 6.53 . These values are in agreement with those 
Savio et al.

Table 1. Total acidity of boneless chicken thighs and drumsticks stored at $-6,-12$ and $-18^{\circ} \mathrm{C}$.

\begin{tabular}{ccrr}
\hline Period (months) & \multicolumn{3}{c}{ Total acidity (g oleic acid/100 g) } \\
\cline { 2 - 4 } & $-6^{\circ} \mathrm{C}$ & $-12^{\circ} \mathrm{C}$ & $-18^{\circ} \mathrm{C}$ \\
2 & $0.12^{\mathrm{cA}} \pm 0.01$ & $0.12^{\mathrm{cA}} \pm 0.01$ & $0.12^{\mathrm{cA}} \pm 0.01$ \\
3 & $0.18^{\mathrm{bcA}} \pm 0.01$ & $0.15^{\mathrm{bcB}} \pm 0.01$ & $0.16^{\mathrm{bAB}} \pm 0.01$ \\
4 & $0.19^{\mathrm{bA}} \pm 0.01$ & $0.17^{\mathrm{bB}} \pm 0.01$ & $0.16^{\mathrm{bB}} \pm 0.01$ \\
8 & $0.19^{\mathrm{bA}} \pm 0.01$ & $0.15^{\mathrm{bB}} \pm 0.01$ & $0.15^{\mathrm{bcB}} \pm 0.01$ \\
9 & $0.21^{\mathrm{abA}} \pm 0.02$ & $0.24^{\mathrm{aA}} \pm 0.02$ & $0.19^{\mathrm{aB}} \pm 0.01$ \\
10 & $0.23^{\mathrm{aA}} \pm 0.01$ & $0.23^{\mathrm{aA}} \pm 0.01$ & $0.22^{\mathrm{aA}} \pm 0.01$ \\
12 & $0.23^{\mathrm{aA}} \pm 0.01$ & $0.25^{\mathrm{aA}} \pm 0.01$ & $0.23^{\mathrm{aA}} \pm 0.02$ \\
& $0.25^{\mathrm{aA}} \pm 0.02$ & $0.25^{\mathrm{aA}} \pm 0.02$ & $0.24^{\mathrm{aA}} \pm 0.02$ \\
\hline
\end{tabular}

Means ( \pm standard deviation) followed by equal lowercase/uppercase letters in columns/rows do not differ statistically at a confidence level of 5\% (Tukey's test).

obtained by Racanicci et al. (2008) using the same samples tested here. The author obtained $\mathrm{pH}$ values from 6.07 to 6.34 .

The results of lipid oxidation of samples of chicken thighs and drumsticks stored at $4{ }^{\circ} \mathrm{C}$ for 8 days and at $-6,-12$ and $-18{ }^{\circ} \mathrm{C}$ for 12 months are presented in Tables 2 and 3, respectively. The MDA values increased gradually during storage, mainly for samples stored at $4,-6$ and $-12^{\circ} \mathrm{C}$, demonstrating the influence of storage time on the oxidation reactions.

The lipid oxidation of samples kept under refrigeration $\left(4^{\circ} \mathrm{C}\right)$ presented a significant difference $(\mathrm{p}<0.05)$ from the fourth day of storage, with a sharp increase at the eighth day of storage, with a mean value of $0.65 \mathrm{mg} \mathrm{MDA} / \mathrm{kg}$ sample, equivalent to approximately 10 times the initial value (0.06 mg MDA/kg sample).

Ahmad \& Srivastava (2007) and Galvin et al. (1997) verified that trained tasters are able to detect undesirable flavours in oxidized meats from lipid oxidation values higher than $0.50 \mathrm{mg} \mathrm{MDA} / \mathrm{kg}$ sample. As will be discussed below, in the present work, after 6 days of storage under refrigeration, the tasters attributed a 'slight difference from the standard sample' for the roast chicken, and after 8 days of storage the samples in natura were characterized as having an undesirable flavour of oxidized meat and a partially deteriorated physical aspect, with TBARS values of $0.65 \mathrm{mg} \mathrm{MDA} / \mathrm{kg}$ sample.

Chouliara et al. (2007) evaluated the shelf life of chicken breasts stored at $4{ }^{\circ} \mathrm{C}$. Enhancement of lipid oxidation from 0.28 to $0.58 \mathrm{mg} \mathrm{MDA} / \mathrm{kg}$ sample was observed from the first to the sixth day of storage. After 25 days, decay was observed (0.10 mg MDA $/ \mathrm{kg})$. Some authors relate that oscillations in TBARS values can occur during storage (Cardoso et al., 2008).

The samples stored at $-6^{\circ} \mathrm{C}$ presented significant differences $(\mathrm{p}<0.05)$ from the second month of storage, showing a sharp increase after the $10^{\text {th }}$ month $(0.67 \mathrm{mg} \mathrm{MDA} / \mathrm{kg})$, keeping this value constant until the $12^{\text {th }}$ month of storage. A similar behaviour was observed in the samples stored at $-12{ }^{\circ} \mathrm{C}$. Samples stored at $-18^{\circ} \mathrm{C}$ also presented a significant difference $(\mathrm{p}<0.05)$ in the $10^{\text {th }}$ month, but with lower TBARS values $(0.30 \mathrm{mg} \mathrm{MDA} / \mathrm{kg})$ compared to the samples kept at -6 and $-12{ }^{\circ} \mathrm{C}$. These samples did not present organoleptic alterations (as will be discussed below) in cooked samples, after the sensory evaluation by the trained tasters. The results obtained here are different from those observed by Soyer et al. (2010). Those authors did not find significant differences in the TBARS values in chicken thighs
Table 2. Lipid oxidation - TBARS - of boneless chicken thighs and drumsticks cooled at $4{ }^{\circ} \mathrm{C}$ during 8 days of storage.

\begin{tabular}{cc}
\hline Period (days) & TBARS $(\mathrm{mg}$ MDA/kg sample) \\
\hline 0 & $0.06^{\mathrm{d}} \pm 0.01$ \\
2 & $0.08^{\mathrm{d}} \pm 0.02$ \\
4 & $0.14^{\mathrm{c}} \pm 0.01$ \\
6 & $0.29^{\mathrm{b}} \pm 0.06$ \\
8 & $0.65^{\mathrm{a}} \pm 0.03$ \\
\hline
\end{tabular}

Means ( \pm standard deviation) followed by equal letters do not differ statistically at a confidence level of $5 \%$ (Tukey's test).

Table 3. Lipid oxidation - TBARS - of boneless chicken thighs and drumsticks stored under freezing at $-6,-12$ and $-18^{\circ} \mathrm{C}$ for 12 months.

\begin{tabular}{cccc}
\hline \multirow{2}{*}{$\begin{array}{c}\text { Period } \\
\text { (months) }\end{array}$} & \multicolumn{3}{c}{ TBARS (mg MDA/kg sample) } \\
\cline { 2 - 4 } & $-6^{\circ} \mathrm{C}$ & $-12^{\circ} \mathrm{C}$ & $-18^{\circ} \mathrm{C}$ \\
\hline 0 & $0.08^{\mathrm{dA}} \pm 0.01$ & $0.08^{\mathrm{dA}} \pm 0.012$ & $0.08^{\mathrm{dA}} \pm 0.01$ \\
2 & $0.29^{\mathrm{bCA}} \pm 0.02$ & $0.10^{\mathrm{dB}} \pm 0.008$ & $0.05^{\mathrm{eC}} \pm 0.01$ \\
3 & $0.34^{\mathrm{bA}} \pm 0.01$ & $0.09^{\mathrm{dB}} \pm 0.005$ & $0.07^{\mathrm{dB}} \pm 0.02$ \\
4 & $0.34^{\mathrm{bA}} \pm 0.05$ & $0.29^{\mathrm{bA}} \pm 0.023$ & $0.19^{\mathrm{CB}} \pm 0.02$ \\
7 & $0.27^{\mathrm{cA}} \pm 0.04$ & $0.27^{\mathrm{bA}} \pm 0.066$ & $0.08^{\mathrm{dB}} \pm 0.02$ \\
8 & $0.26^{\mathrm{cA}} \pm 0.02$ & $0.20^{\mathrm{CA}} \pm 0.021$ & $0.10^{\mathrm{dB}} \pm 0.02$ \\
10 & $0.67^{\mathrm{aA}} \pm 0.04$ & $0.52^{\mathrm{aA}} \pm 0.060$ & $0.30^{\mathrm{bB}} \pm 0.06$ \\
12 & $0.68^{\mathrm{aA}} \pm 0.05$ & $0.54^{\mathrm{aA}} \pm 0.07$ & $0.36^{\mathrm{aB}} \pm 0.07$ \\
\hline
\end{tabular}

Means ( \pm standard deviation) followed by equal lowercase/uppercase letters in columns/ rows do not differ statistically at a confidence level of 5\% (Tukey's test).

and drumsticks after a period of storage of about 6 months, at different temperatures $\left(-7,-12\right.$ and $\left.-18^{\circ} \mathrm{C}\right)$. It is important to observe that in the work by Soyer et al. (2010), the samples were frozen at $-7,-12$ and $-18{ }^{\circ} \mathrm{C}$ and then stored at $-18^{\circ} \mathrm{C}$. In the present study, the samples were firstly frozen, and then stored at $-6,-12$ and $-18^{\circ} \mathrm{C}$.

Comparing the frozen samples stored for 12 months at $-6,-12$ and $-18{ }^{\circ} \mathrm{C}$ (Table 3 ) and those cooled at $4{ }^{\circ} \mathrm{C}$ and stored for 8 days (Table 2 ), one can observe that the oxidation level reached by the cooled sample $(0.654 \mathrm{mg} \mathrm{MDA} / \mathrm{kg})$ is equivalent to approximately 10 times of those stored at $-6^{\circ} \mathrm{C}$. On the other hand, the samples stored at -12 and $-18{ }^{\circ} \mathrm{C}$ for 12 months had TBARS values lower than $0.6 \mathrm{mg} \mathrm{MDA} / \mathrm{kg}$, confirming the effect of temperature on the rate of lipid oxidation reactions. 
Oxidation is one of the main factors involved in the deterioration of lipid compounds of meat, especially of unsaturated fatty acids. Chicken and fish meat is characterized as having a relatively high content of these kinds of fatty acid, more susceptible to oxidative deterioration compared to other kinds of meat (Maggioni et al., 2008; Morachis-Valdez et al., 2017).

The samples of boneless chicken thighs and drumsticks kept under freezing presented oscillations of the TBARS values from the fourth to the eighth month of storage. Several authors suggest that the reduction in TBARS values observed during storage time is probably associated with the increase in concentration of polar compounds resulting from the polymerization of secondary oxidation products. It has already been related that MDA can react with a great number of compounds or can also produce dienes or trienes of MDA, reducing the amount of MDA available to react with thiobarbituric acid, leading to lower TBARS values (Grau et al., 2001; Gatellier et al., 2007).

Table 4 presents the protein oxidation values of samples of boneless chicken thighs and drumsticks stored for 12 months at temperatures of $-6,-12$ and $-18^{\circ} \mathrm{C}$. The initial protein oxidation was $5.37 \mathrm{nmol}$ carbonyl $/ \mathrm{mg}$ protein. The frozen samples presented different values of protein oxidation during storage. The samples kept at $-18^{\circ} \mathrm{C}$ did not present a difference compared to the first day of storage. However, the samples stored at $-6^{\circ} \mathrm{C}$ presented higher protein oxidation (23.23 nmol carbonyl/mg protein) during the period of storage (12 months) than the other tested treatments.

Temperature presented a significant influence on the rate of oxidative reaction (both protein and lipid). The samples stored at $-18^{\circ} \mathrm{C}$ presented lower values of MDA and carbonyl compared to those kept at -6 and $-12^{\circ} \mathrm{C}$ (Tables 3 and 4). A possible cause for the elevation of carbonyl groups after 12 months of storage at -6 and $-12{ }^{\circ} \mathrm{C}$ could be related to lipid oxidation. Howell et al. (2001) have already demonstrated that protein oxidation is related to lipid oxidation in meat products. Compared to lipid oxidation, the degradation of proteins by oxidants seems to be more complex and to produce an even greater multiplicity of reaction products and certain protein oxidation products may be active at water-lipid interfaces in meat (Jongberg et al., 2017).

\subsection{Sensory characteristics}

Tables 5 and 6 present the results of sensory characteristics of boneless chicken samples (in natura and roasted) stored at $4,-6,-12$ and $-18{ }^{\circ} \mathrm{C}$.

The samples of thighs and drumsticks in natura kept at $4{ }^{\circ} \mathrm{C}$ presented a significant difference $(\mathrm{p}<0.05)$ in flavour after 4 days of storage compared to the standard sample (0 days of storage). The cooled samples presented an intense and unpleasant flavour and physical aspects of deteriorated product after 8 days of storage. Based on these aspects, the samples were considered unacceptable for consumption. It is relevant to mention that this product normally presents a shelf life of 7 days, based on the quality programs adopted by the food industry.

The samples in natura stored at -6 and $-12{ }^{\circ} \mathrm{C}$ presented a significant difference $(\mathrm{p}<0.05)$ compared to those at $-18^{\circ} \mathrm{C}$ from the eighth month of storage (Table 6). The global evaluation
Table 4. Protein oxidation of boneless chicken thighs and drumsticks stored under freezing at $-6,-12$ and $-18{ }^{\circ} \mathrm{C}$ for 12 months.

\begin{tabular}{ccc}
\hline Treatment & $\begin{array}{c}\text { Period } \\
\text { (month) }\end{array}$ & $\begin{array}{c}\text { Protein oxidation } \\
\text { (nmol carbonyl/mg protein) }\end{array}$ \\
\hline Standard & 0 & $5.37^{\mathrm{c}} \pm 1.13$ \\
Stored at $-6^{\circ} \mathrm{C}$ & 12 & $23.23^{\mathrm{a}} \pm 1.04$ \\
Stored at $-12^{\circ} \mathrm{C}$ & 12 & $17.53^{\mathrm{b}} \pm 0.38$ \\
Stored at $-18^{\circ} \mathrm{C}$ & 12 & $6.03^{\mathrm{c}} \pm 0.09$ \\
\hline
\end{tabular}

Means ( \pm standard deviation) followed by equal letters do not differ statistically at a confidence level of $5 \%$ (Tukey's test).

Table 5. Sensory characteristics of cooled boneless chicken thighs and drumsticks for different periods of storage at $4{ }^{\circ} \mathrm{C}$.

\begin{tabular}{ccccc}
\hline & \multicolumn{4}{c}{ Sensory characteristic } \\
\cline { 2 - 5 } $\begin{array}{c}\text { Period } \\
\text { (days) }\end{array}$ & $\begin{array}{c}\text { Visual aspect and flavour } \\
\text { Sample in natura }\end{array}$ & \multicolumn{2}{c}{$\begin{array}{c}\text { Global evaluation } \\
\text { Cooked sample }\end{array}$} \\
\cline { 2 - 5 } & Standard $^{*}$ & Sample & Standard & Sample \\
\hline 2 & $1.40^{\mathrm{aA}}$ & $1.50^{\mathrm{bA}}$ & $1.11^{\mathrm{aA}}$ & $1.44^{\mathrm{bA}}$ \\
4 & $0.90^{\mathrm{aB}}$ & $4.20^{\mathrm{aA}}$ & $1.00^{\mathrm{aA}}$ & $1.60^{\mathrm{bA}}$ \\
6 & $0.70^{\mathrm{aB}}$ & $4.40^{\mathrm{aA}}$ & $0.67^{\mathrm{aB}}$ & $3.33^{\mathrm{aA}}$ \\
8 & - & Unacceptable $^{* *}$ & - & Unacceptable $^{\star *}$ \\
\hline
\end{tabular}

Means followed by equal lowercase/uppercase letters in columns/rows do not differ statistically at a confidence level of $5 \%$ (Dunnett's and Tukey's tests on rows and columns, respectively); ${ }^{*}$ Standard - 0 days of storage; ${ }^{*}$ Unacceptable - unsuitable for consumption.

Table 6. Sensory characteristics of cooled boneless chicken thighs and drumsticks in natura and cooked, for different periods of storage at $-6,-12$ and $-18{ }^{\circ} \mathrm{C}$.

\begin{tabular}{|c|c|c|c|c|c|c|}
\hline \multirow{3}{*}{$\begin{array}{l}\text { Period } \\
\text { (months) }\end{array}$} & \multicolumn{6}{|c|}{ Visual aspect and flavour - in natura } \\
\hline & \multicolumn{2}{|c|}{$-6^{\circ} \mathrm{C}$} & \multicolumn{2}{|c|}{$-12^{\circ} \mathrm{C}$} & \multicolumn{2}{|c|}{$-18^{\circ} \mathrm{C}$} \\
\hline & Standard* & Sample & Standard* & Sample & Standard $^{*}$ & Sample \\
\hline 2 & $1.00^{\mathrm{aA}}$ & $1.33^{\mathrm{bA}}$ & $1.00^{\mathrm{aA}}$ & $1.33^{\mathrm{dA}}$ & $1.00^{\mathrm{aA}}$ & $1.33^{\mathrm{bA}}$ \\
\hline 4 & $1.17^{\mathrm{aA}}$ & $1.33^{\mathrm{bA}}$ & $1.17^{\mathrm{aA}}$ & $1.83^{\mathrm{dA}}$ & $1.17^{\mathrm{aA}}$ & $1.67^{\mathrm{bA}}$ \\
\hline 5 & $0.75^{\mathrm{aA}}$ & $1.50^{\mathrm{bA}}$ & $0.75^{\mathrm{aA}}$ & $1.63^{\mathrm{dA}}$ & $0.75^{\mathrm{aA}}$ & $1.75^{\mathrm{bA}}$ \\
\hline 6 & $0.50^{\mathrm{aB}}$ & $2.67^{\mathrm{abA}}$ & $0.50^{\mathrm{aB}}$ & $3.00^{\mathrm{cA}}$ & $0.50^{\mathrm{aA}}$ & $1.17^{\mathrm{bA}}$ \\
\hline 8 & $1.20^{\mathrm{aB}}$ & $4.80^{\mathrm{aA}}$ & $1.20^{\mathrm{aB}}$ & $4.20^{\mathrm{bA}}$ & $1.20^{\mathrm{aB}}$ & $4.83^{\mathrm{aA}}$ \\
\hline 9 & $0.80^{\mathrm{aB}}$ & $5.43^{\mathrm{aA}}$ & $0.80^{\mathrm{aB}}$ & $5.60^{\mathrm{aA}}$ & $0.80^{\mathrm{aB}}$ & $4.00^{\mathrm{aA}}$ \\
\hline 10 & $0.40^{\mathrm{aB}}$ & $5.60^{\mathrm{aA}}$ & $0.40^{\mathrm{aB}}$ & $5.73^{\mathrm{aA}}$ & $0.40^{\mathrm{aB}}$ & $4.86^{\mathrm{aA}}$ \\
\hline \multirow[t]{2}{*}{12} & $0.62^{\mathrm{aB}}$ & $5.64^{\mathrm{aA}}$ & $0.62^{\mathrm{aB}}$ & $5.86^{\mathrm{aA}}$ & $0.62^{\mathrm{aB}}$ & $4.92^{\mathrm{aA}}$ \\
\hline & \multicolumn{6}{|c|}{ Global evaluation - Cooked samples } \\
\hline 2 & $0.44^{\mathrm{aB}}$ & $1.22^{\mathrm{bB}}$ & $0.44^{\mathrm{aB}}$ & $1.22^{\mathrm{bB}}$ & $0.44^{\mathrm{aB}}$ & $1.33^{\mathrm{aB}}$ \\
\hline 4 & $0.83^{\mathrm{aB}}$ & $1.67^{\mathrm{bB}}$ & $0.83^{\mathrm{aB}}$ & $1.33^{\mathrm{bB}}$ & $0.83^{\mathrm{aB}}$ & $1.53^{\mathrm{aB}}$ \\
\hline 5 & $0.71^{\mathrm{aB}}$ & $2.86^{\mathrm{bA}}$ & $0.71^{\mathrm{aB}}$ & $2.14^{\mathrm{bA}}$ & $0.71^{\mathrm{aB}}$ & $1.61^{\mathrm{aB}}$ \\
\hline 6 & $1.00^{\mathrm{aB}}$ & $1.83^{\mathrm{bA}}$ & $1.00^{\mathrm{aB}}$ & $1.83^{\mathrm{bA}}$ & $1.00^{\mathrm{aB}}$ & $1.67^{\mathrm{aB}}$ \\
\hline 8 & $1.10^{\mathrm{aB}}$ & $3.20^{\mathrm{aA}}$ & $1.10^{\mathrm{aB}}$ & $2.80^{\mathrm{bA}}$ & $1.10^{\mathrm{aB}}$ & $1.75^{\mathrm{aB}}$ \\
\hline 9 & $1.00^{\mathrm{aB}}$ & $3.29^{\mathrm{aA}}$ & $1.00^{\mathrm{aB}}$ & $3.50^{\mathrm{aA}}$ & $1.00^{\mathrm{aB}}$ & $1.80^{\mathrm{aB}}$ \\
\hline 10 & $1.00^{\mathrm{aB}}$ & $3.00^{\mathrm{aA}}$ & $1.00^{\mathrm{aB}}$ & $3.09^{\mathrm{abA}}$ & $1.00^{\mathrm{aB}}$ & $1.75^{\mathrm{aB}}$ \\
\hline 12 & $1.10^{\mathrm{aB}}$ & $3.18^{\mathrm{aA}}$ & $1.10^{\mathrm{aB}}$ & $3.21^{\mathrm{aA}}$ & $1.10^{\mathrm{aB}}$ & $1.79^{\mathrm{aB}}$ \\
\hline
\end{tabular}

Means followed by equal lowercase/uppercase letters in columns/rows do not differ statistically at a confidence level of 5\% (Dunnett's and Tukey's test on rows and columns, respectively). Values of sensory criteria: 0 - No difference; 2 - Slightly different; 4 - Moderately different; 6 - Very different; 8 - Extremely different; ${ }^{*}$ Standard - 0 days of storage.

of roasted samples presented a significant difference $(\mathrm{p}<0.05)$ from the fifth month when stored at -6 and $-12{ }^{\circ} \mathrm{C}$. Roasted samples stored at $-18{ }^{\circ} \mathrm{C}$ did not present differences compared to the standard ones during the whole period of storage. 
Racanicci et al. (2008) showed that samples of chicken meat fed with different lipid sources and stored at $-18{ }^{\circ} \mathrm{C}$ presented sufficient oxidative and organoleptic quality for consumption until 6 months. Probably, the difference in storage time compared to the present work (Table 5) can be attributed to the different animal feed and also to the freezing process employed. Zapata et al. (2006) evaluated alterations promoted by the freezing process in chicken drumsticks stored at $-20^{\circ} \mathrm{C}$ for 30 days. The alterations observed as a function of genetic group during storage under freezing did not influence the global characteristics and the flavour and texture of the product. Leone (2008) did not observe a statistical difference for the sensory attributes in samples of irradiated chicken kept frozen at $-20^{\circ} \mathrm{C}$ for periods of $0,2,4$ and 6 months of storage.

\subsection{Microbiological analysis}

The samples of boneless chicken drumsticks and thighs presented an initial microbial count of $3.5 \log \mathrm{CFU} / \mathrm{g}$. The cooled samples showed a progressive increase until the sixth day of storage (6.8 log CFU/g). The initial value was close to that obtained by Galarz et al. (2010) using samples of chicken breast $(3.6 \log \mathrm{CFU} / \mathrm{g})$. The temperature $\left(4^{\circ} \mathrm{C}\right)$ and other variables, such as water content and the presence of oxygen in the atmosphere that surrounds the product, are factors that make possible the reproduction of microorganisms present in the samples. It is important to mention that the samples presented a high water content, from 0.994 (first day) to 0.992 (eighth day of storage). Taking into account this information, the samples were susceptible to deterioration by microorganisms and could also accelerate chemical reactions (lipid oxidation, for example) during storage.

After 12 months of storage at -12 and $-18^{\circ} \mathrm{C}$ the microorganism count in the samples remained stable. However, samples stored at $-6^{\circ} \mathrm{C}$ presented microorganism growth from the ninth month, reaching $6.8 \log \mathrm{CFU} / \mathrm{g}$ after 12 months.

Studies carried out using breaded chicken breast and processed chicken hamburgers stored at $-18^{\circ} \mathrm{C}$ for 180 days showed that no significant differences were achieved in the microbial population during the storage time (initial psychrotrophic count of 4.9 and final count of $3.43 \log$ CFU/g) (Komiyama et al., 2009).

Brazilian legislation does not have any register of standard established for the counting of psychrotrophic microorganisms, although it indicates the degree of deterioration of cooled food (Galarz et al., 2010). However, the International Commission on Microbiological Specifications for Foods (1978) established $10^{6}$ to $10^{7} \mathrm{CFU} / \mathrm{g}$ (6 to $7 \mathrm{log} \mathrm{CFU} / \mathrm{g}$ ) as standard for this class of microorganism. Other authors recommend values from $10^{6}$ to $10^{8} \mathrm{CFU} / \mathrm{g}$ (Senter et al., 2000; Smolander et al., 2004; Ordóñez-Pereda et al., 2005). Nurmi \& Ring (1999) indicated that if the number of bacteria on the meat surface was higher than $10^{8} \mathrm{CFU} / \mathrm{g}$, the product could be considered unfeasible for human consumption. A microbiological count of $10^{7} \mathrm{CFU} / \mathrm{g}$ characterizes the product as of 'bad quality'.

The psychrotrophic count in samples of chicken thighs and drumsticks presented by Carvalho et al. (2005) varied from $7.1 \times 10^{3}$ to $1.3 \times 10^{6} \mathrm{CFU} / \mathrm{g}$. Hoffman et al. (1995) observed a count of about $10^{4}$ to $10^{6} \mathrm{CFU} / \mathrm{g}$ in samples of chicken carcass and Vieira \& Teixeira (1997) obtained counts from $2.0 \times 10^{1}$ to $3.4 \times 10^{5} \mathrm{CFU} / \mathrm{g}$ in the same kind of sample.

At this point it is important to observe that the storage of meat and derivatives under refrigeration, covered by an oxygen-permeable film, originates a high redox potential on the surface of the product, suitable for the development of psychrotrophic microorganisms. Gram-negative bacilli grow rapidly in these conditions, and can be responsible for the development of undesirable alterations (Adams \& Moss, 1997). Moreover, it is relevant to mention that the shelf life of meat has an inverse relation to the initial contamination of the product (Davies \& Board, 1998; Barbut, 2002; Jay, 2005).

\section{Conclusion}

The temperature-time relationship influenced sensory stability, lipid, protein and microbiological samples of thighs and drumsticks Boneless chicken. The sensory analysis of samples in natura stored at $4{ }^{\circ} \mathrm{C}$ showed significant differences in shorter storage time than roasted samples. In the samples stored at -6 and $-12{ }^{\circ} \mathrm{C}$, changes were detected in the sensory characteristics in the 8 and 9 th month of storage, respectively, while the samples at $-18^{\circ} \mathrm{C}$, was not verified change during 12 months of storage. The lipid oxidation showed similar behavior for samples stored at $4{ }^{\circ} \mathrm{C}$ on day 8 compared the packed -6 and $-12{ }^{\circ} \mathrm{C}$ in the 10 th month of storage. Samples stored at $-18{ }^{\circ} \mathrm{C}$ showed the lowest TBARS values and changes not were detected on the organoleptic characteristics of the roasted samples. Regarding protein oxidation, only the samples stored for 12 months at $-18{ }^{\circ} \mathrm{C}$ did not differ to the control. In relation to microbiological evaluation, there was a sharp growth of psychrotrophic with storage at 4 and $-6^{\circ} \mathrm{C}$, not observed in the samples stored at -12 and $-18{ }^{\circ} \mathrm{C}$. Thus, the maximum storage period was 6 days at $4{ }^{\circ} \mathrm{C}, 8$ months at -6 and $-12^{\circ} \mathrm{C}$ and at least 12 months storage at $-18^{\circ} \mathrm{C}$.

\section{Acknowledgements}

The authors thank the CAPES, CNPq, FAPERGS and URI for financial support.

\section{References}

Adams, M. R., \& Moss, M. O. (1997). Microbiologia de los alimentos. España: Acribia.

Ahmad, S., \& Srivastava, P. K. (2007). Quality and shelf life evaluation of fermented suasages of buffalo meat with different levels of heart and fat. Meat Science, 75(4), 603-609. http://dx.doi.org/10.1016/j. meatsci.2006.09.008. PMid:22064024.

Altunatmaz, S. S., Issa, G., \& Aydin, A. (2012). Detection of airborne psychrotrophic bacteria and fungi in food storage refrigerators. Brazilian Journal of Microbiology, 43(4), 1436-1443. http://dx.doi. org/10.1590/S1517-83822012000400027. PMid:24031974.

Andrade, E. C. B., Barros, A. M., Mello, V. S., \& Takase, I. (2004). Evaluation of copper and zinc in meats thermally processed and conservated in freezer for a month. Food Science and Technology, 24(3), 393-396. http://dx.doi.org/10.1590/S0101-20612004000300016.

Association of Official Analytical Chemists - AOAC. (1990). Official methods of analysis of the Association of Official Analytical Chemists (15th ed., pp. 1298). Arlington: AOAC. 
Barbut, S. (2002). Poultry products processing: an industry guide (pp. 548). Boca Raton: CRC Press.

Brasil, Ministério da Agricultura. (1998, November 26). Aprovar o regulamento técnico da inspeção tecnológica e higiênico-sanitária de carne de aves (Portaria no 210, de 10 de novembro de 1998). Diário Oficial [da] República Federativa do Brasil.

Cardoso, C., Mendes, R., Pedro, S., \& Nunes, L. (2008). Quality canges during storage of fish sausages containing dietary fiber. Journal of Aquatic Food Product Technology, 17(1), 73-95. http://dx.doi. org/10.1080/10498850801891249.

Carvalho, A. C. F. B., Cortez, A. L. L., Salotti, B. M., Bürger, K. P., \& Vidal-Martins, A. M. C. (2005). Presence of mesophilic, psychophilic and coliform microorganism in different samples of poultry products. Arquivos do Instituto Biológico, 72, 303-307.

Chouliara, E., Karatapanis, A., Savvaidis, I. N., \& Kontominas, M. G. (2007). Combined effect of oregano essential oil and modified atmosphere packaging on shelf-life extending of fresh chicken breast meat, stored at $4{ }^{\circ} \mathrm{C}$. Food Microbiology, 24(6), 607-617. http://dx.doi. org/10.1016/j.fm.2006.12.005. PMid:17418312.

Conceição, F. V. E., \& Gonçalves, E. C. B. A. (2009). Quality physicistchemistry of mortadelas and pounded meats and knowledge of the consumer in the conservation of these. Food Science and Technology, 29, 283-290.

Dave, D., \& Ghaly, A. E. (2011). Meat spoilage mechanisms and preservation techniques: a critical review. American Journal of Agricultural and Biological Sciences, 6(4), 486-510. http://dx.doi. org/10.3844/ajabssp.2011.486.510.

Davies, A., \& Board, R. (1998). The microbiology of meat and poultry (pp. 346). London: Blackie Academic \& Professional.

De Paula, R., Soares, J. M., Silva, P. F., Backes, G. T., Cansian, R. L., Treichel, H., \& Valduga, E. (2017). Assessment of different packaging structures in the stability of refrigerated fresh Brazilian Toscana sausage. International Food Research Journal, 24(1), 173-181.

Elsedig, E. A. A., Mohd, M. I., \& Fatimah, M. A. (2015). Assessing the competitiveness and comparative advantage of broiler production in Johor using policy analysis matrix. International Food Research Journal, 22(1), 116-121.

Faria, E., \& Yotsuyanagi, K. (2002). Técnicas de análise sensorial (pp. 116). Campinas: ITAL/LAFISE.

Galarz, L. A., Fonseca, G. G., \& Prentice-Hernández, C. (2010). Microbial growth in chicken breast products during supply chain simulation. Food Science and Technology, 30(4), 870-877. http:// dx.doi.org/10.1590/S0101-20612010000400006.

Galvin, K., Morrissey, P. A., \& Buckley, D. J. (1997). Influence of dietary vitamin $\mathrm{E}$ and oxidized sunflower oil on the storage stability of cooked chicken muscle. British Poultry Science, 38(5), 499-504. http://dx.doi.org/10.1080/00071669708418028. PMid:9510993.

Gatellier, P., Gomez, S., Gigaud, V., Berri, C., Bihan-Duval, E. L., \& Sante-Lhoutellier, V. (2007). Use of a fluorescence front face technique for measurement of lipid oxidation during refrigerated storage of chicken meat. Meat Science, 76(3), 543-547. http://dx.doi. org/10.1016/j.meatsci.2007.01.006. PMid:22060998.

Grau, A., Guardiola, F., Grimpa, S., Barroeta, A. C., \& Codony, R. (2001). Oxidative stability of dark chicken meat through frozen storage: influence of dietary fat and $\alpha$ - tocopherol and ascorbic acid supplementation. Poultry Science, 80(11), 1630-1642. http://dx.doi. org/10.1093/ps/80.11.1630. PMid:11732681.

Hoffman, F. L., Garcia-Cruz, C. H., \& Venturim, T. M. (1995). Estudo higiênico sanitário de frangos comercializados na cidade de São José do Rio Preto-SP. Higiene Alimentar, 9, 31-33.
Howell, N. K., Herman, H., \& Li-Chan, E. C. Y. (2001). Elucidation of protein-lipid interactions in lysozyme: corn oil system by fourier transform raman spectroscopy. Journal of Agricultural and Food Chemistry, 49(3), 1529-1533. http://dx.doi.org/10.1021/jf001115p. PMid:11312891.

International Commission on Microbiological Specifications for Foods - ICMSF. (1978). Microorganisms in foods: their significance and methods of enumeration. Toronto: University of Toronto.

Jay, J. M. (2005). Microbiologia de alimentos (E. C. Tondo, Trans.), 6th ed. Porto Alegre: Artmed.

Jayas, D. S., \& Jeyamkondan, S. (2002). Modified atmosphere storage of grains, meats, fruits and vegetables. Biosystems Engineering, 82(3), 235-251. http://dx.doi.org/10.1006/bioe.2002.0080.

Jongberg, S., Lund, M. N., \& Skibsted, L. H. (2017). Protein oxidation in meat and meat products: challenges for antioxidative protection. In G. Barbosa-Cánovas, G. M. Pastore, K. Candoğan, I. G. M. Meza, S. C. S. Lannes, K. Buckle, R. Y. Yada \& A. Rosenthal (Eds.), Global food security and wellness. New York: Springer. http://dx.doi. org/10.1007/978-1-4939-6496-3_17.

Komiyama, C. M., Mendes, A. A., Takahashi, S. E., Moreira, J., Borba, H. B. A., Leonel, F. R., Roça, R. O., Almeida, I. C. L. P., \& Balog, A. No. (2009). Qualitative characteristics of products produced with pale and normal broiler chicken meat. Food Science and Technology, 29(1), 38-45. http://dx.doi.org/10.1590/S0101-20612009000100007.

Leone, F. R. (2008). Irradiação e qualidade da carne de frango congelada e embalada a vácuo (Tese de doutorado). Faculdade de Ciências Agrárias e Veterinárias, Universidade Estadual Paulista, Jaboticabal.

Levine, R. L., Reznick, A. Z., \& Packer, L. (1990). Oxidative damage to proteins: spectrophotometric method for carbonyl assay. Methods in Enzymology, 186, 357-363. PMid:8015470.

Lyon, B. G., \& Lyon, C. E. (2002). Color of uncooked and cooked broiler leg quarters associated with chilling temperature and holding time. Poultry Science, 81(12), 1916-1920. http://dx.doi.org/10.1093/ ps/81.12.1916. PMid:12512587.

Maggioni, D., Rotta, P. P., Prado, R. M., Zawadzki, F., Ito, R. H., \& Prado, I. N. (2008). Fatores que afetam a estabilidade da carne. Revista Nacional da Carne, 374, 73-77.

Morachis-Valdez, A. G., Gómez-Oliván, L. M., García-Argueta, I., Hernández-Navarro, M. D., Diaz-Bandera, D., \& Dublán-Garcia, O. (2017). Effect of chitosan edible coating on the biochemical and physical characteristics of carp fillet (Cyprinus carpio) stored at - 18 ${ }^{\circ} \mathrm{C}$. International Journal of Food Sciences, 2017, 1-10. http://dx.doi. org/10.1155/2017/2812483. PMid:28634584.

Mürmann, L., Dilkin, P., Kowalski, C. H., Almeida, C. A., \&Mallmann, C. A. (2004). Conservatives temperatures of cold in establishments that food trade, from Santa Maria / RS City.Higiene Alimentar, 18(124), 30-34.

Murray, R., Glass-Kaastra, S., Gardhouse, C., Marshall, B., Ciampa, N., Franklin, K., Hurst, M., Thomas, M. K., \& Nesbitt, A. (2017). Canadian consumer food safety pratices and knowledge: foodbook study. Journal of Food Protection, 80(10), 1711-1718. http://dx.doi. org/10.4315/0362-028X.JFP-17-108. PMid:28906156.

Nurmi, E., \& Ring, C. (1999). Production of hygienically justifiable mechanically recovered meat. Fleischwirtschaft International, 2, 21-22.

O'Connell, A., Ruegg, P. L., Jordan, K., O’Brien, B., \& Gleeson, D. (2016). The effect of storage temperature and duration on the microbial quality of bulk tank milk. Journal of Dairy Science, 99(5), 33673374. http://dx.doi.org/10.3168/jds.2015-10495. PMid:26947309.

Ordóñez-Pereda, J. A., Rodríguez, M. I. C., Álvarez, L. F., Sanz, M. L. G., Minguillón, G. D. G. F., Perales, L. H., \&Cortecero, M. D. S. 
(2005). Tecnologia de alimentos: alimentos de origem animal (2nd ed., pp. 291). Porto Alegre: Artmed.

Osimani, A., Aquilanti, L., Tavoletti, A., \& Clementi, F. (2013). Evaluation of the HACCP system in a University Canteen: microbiological monitoring and internal auditing as verification tools. International Journal of Environmental Research and Public Health, 10(4), 15721585. http://dx.doi.org/10.3390/ijerph10041572. PMid:23594937.

Paine, F. A., \& Paine, H. Y. (1983). A handbook of food packing (pp. 497). Glasgow: Blakie Academic \& Professional.

Racanicci, A. M. C., Menten, J. F. M., D’Arce, M. A. B. R., \& Pino, L. M. (2008). Efeito do uso de óleo de vísceras de aves oxidado na ração de frangos de corte sobre o desempenho, a composição da carcaça e a estabilidade oxidativa da carne da sobrecoxa. Revista Brasileira de Zootecnia, 37(3), 443-449. http://dx.doi.org/10.1590/ S1516-35982008000300009.

Raharjo, S., Sofos, J. N., \& Schmidt, G. R. (1992). Improved speed, specificity, and limit of determination of an aqueous acid extraction thiobarbituric acid- $\mathrm{C}_{18}$ method for measuring lipid peroxidation in beef. Journal of Agricultural and Food Chemistry, 40(11), 2182-2185. http://dx.doi.org/10.1021/jf00023a027.

Rosmini, M. R., Perez-Alvarez, J. A., \& Fernandez-Lopez, J. (2004). Operational processes for frozen red meat. In Y. H. Hui, P. Cornillon, I. G. Legaretta, M. H. Lim, K. D. Murrell \& W. Kit Nip (Eds.), Handbook of frozen foods (pp. 177-179). New York: Marcel Dekker.

Senter, S. D., Arnold, J. W., \& Chew, V. (2000). APC values and volatile compounds formed in commercially processed, raw chicken parts during storage at 4 and $13^{\circ} \mathrm{C}$ and under simulated temperature abuse conditions. Journal of the Science of Food and Agriculture, 80(10), 1559-
1564. http://dx.doi.org/10.1002/1097-0010(200008)80:10<1559::AIDJSFA686>3.0.CO;2-8.

Smolander, M., Alakomi, H.-L., Ritvanen, T., Vainionpää, J., \& Ahvenainen, R. (2004). Monitoring of the quality of modified atmosphere packaged broiler chicken cuts stored in different temperature conditions. A. Time-temperature indicators as quality indicating tools. Food Control, 15(3), 217-229. http://dx.doi.org/10.1016/S0956-7135(03)00061-6.

Southgate, D. (1992). Conservación de frutas e hortalizas (14th ed., pp. 216). Zaragoza: Editorial Acribia.

Soyer, A., Özalp, B., Dalmis, Ü., \& Bilgin, V. (2010). Effects of freezing temperature and duration of frozen storage on lipid and protein oxidation in chicken meat. Turkey Food Chemistry, 120(4), 10251030. http://dx.doi.org/10.1016/j.foodchem.2009.11.042.

Terra, N. N., \& Brum, A. R. M. (1998). Carne e seus derivados: técnicas de controle de qualidade (pp. 120). São Paulo: Ed. Nobel.

Vieira, C. R. N., \& Teixeira, C. G. (1997). Condições higiênico-sanitárias de carcaças resfriadas de frango comercializadas em Poços de Caldas-MG. Higiene Alimentar, 11, 36-40.

Yoon, K. S. (2002). Texture and microstructure properties of frozen chicken breasts pretreated with salt and phosphate solutions. Poultry Science, 81(12), 1910-1915. http://dx.doi.org/10.1093/ps/81.12.1910. PMid:12512586.

Zapata, J. F. F., Andrade, A. A., Assunção, G. B., Abreu, V. K. G., Bareto, S. C. S., Fuentes, M. F. F., Freitas, E. R., \& Garuti, D. S. (2006). Preliminary evaluation of the effect of frozen storage on the quality of breast meat from two genetic groups of chickens. Brazilian Journal of Food Technology, 9, 185-191. 